\title{
MULTIPLICATION OF Echinacea purpurea (L.) Moench BY USING TISSUE CULTURE TECHNIQUE
}

(Received: 10.2.2010)

\author{
By \\ S. Sakr , A. Abdou , Sh. Kotb * and N. Eid* \\ Department of Ornamental Horticulture, Faculty of Agriculture, Cairo University, Giza, Egypt. \\ * Department of Medicinal and Aromatic Plants, Horticulture Research Institute, \\ Agricultural Research Center, Giza, Egypt.
}

\begin{abstract}
This study was conducted in the Plant Tissue Culture Laboratory, Horticulture Research Institute in April 2009 to determine the best concentration of Thidiazorone (TDZ) hormone to be used in the media on which explants of Echinacea purpurea are cultured during the multiplication stage.

Coated and de-coated seeds were sterilized using commercial sodium hypochlorite or hydrogen peroxide, germinated in vitro under darkness or light conditions. The resulting seedlings were used as a source for sterilized explants and used in callus induction.

Different kinds of explants (leaves, stems and roots) were cultured on MS media supplemented with different concentrations of TDZ $(0,0.1,0.5,1,2,3,4$ and $5 \mathrm{mg} / \mathrm{L})$. After 45 days, the callus resulting from each of the TDZ treatments were either subcultured on of MS hormone -free medium or Ms medium with the same TDZ concentrations used during callus induction.

The present results showed that the highest percentage of seed germination was $38.89 \%$ obtained when coated seeds were sterilized with $\mathrm{H}_{2} \mathrm{O}_{2}$ and incubated in light. Leaf explants were the most responding to callus initiation medium and the highest fresh weight value resulted from applying $2 \mathrm{mg} / \mathrm{L}$ TDZ, followed by stem explants at $1 \mathrm{mg} / \mathrm{L}$. The highest number of shoots ( 3 shoots / leaf explant) was obtained from leaf explants when subcultured on the media containing the same concentration of hormone $(1 \mathrm{mg} / \mathrm{L} \mathrm{TDZ})$.
\end{abstract}

Key words: Echinacea purpurea, hydrogen peroxide, light, micropropagation, seed germination, sterilization, thidiazorone(TDZ).

\section{INTRODUCTION}

Echinacea purpurea (L.) Moench is one of the most famous medicinal plants native to North America belonging to the Asteraceae family.

It is probably the most widely used herbal medicine in the English-speaking world (Bone, 1997). The annual sales of Echinacea products have been estimated at $\$ 300$ million in the U.S. A alone (Barrett, 2003).

This plant has traditional medicinal uses, including application as an immunostimulant for flu and colds, and as a healing promoter for wounds and throat infections; the most frequent therapeutic and prophylactic applications are for: chronic and recurrent infections of respiratory and urogenital organs, chronic inflammations and allergies, tonsillitis and sinusitis, infected wounds, eczema and psoriasis, chronic bronchitis, and malignancies. Both cortisone-like and immunostimulant activity have been confirmed in
Echinacea plant extract (Coker and Camper, 2000).

The therapeutic effect of Echinacea has been attributed to the presence of caffeic acid derivatives such as chichoric acid, echinacoside, chlorogenic acid and lipophilic polyacetylenederived compounds, such as alkylamides, constituting isobutylamides and various other compounds found in the hydroalcoholic extracts (Letchamo et al., 1999)

Tissue culture is one of the possible recovery ways for some endangered and over-harvested medicinal species (Coker and Camper, 2000) especially in view of the common occurrence of seed dormancy which decreases the reproductive potential of the plant.

Thidiazuron (TDZ), a urea-derived cytokinin, is a potent cytokinin for woody plant tissue culture (Huetteman and Preece, 1993) and is extensively used for the induction of shoot regeneration in 
several plant species (Liu et al., 2003).

The objective of this study was to overcome the difficulties in propagation of Echinacea purpurea, and to develop an in vitro regeneration method by using TDZ; an effective cytokinine during the callus induction and multiplication stage of micropropagation.

\section{MATERIALS AND METHODS \\ 2.1.Plant material}

Seeds of Echinacea purpurea were obtained from The Horticulture Research Institute, Kaha Farm, Agricultural Research Center, Ministry of Agriculture, in 2007 and reserved in plastic bags at room temperature till usage in April 2009 at the Plant Tissue Culture Laboratory.

\subsection{Seed sterilization}

E. purpurea seeds were divided into two groups; normal coated seeds and seeds with the outer coat removed (de- coated seeds).

All seeds were washed with tap water for 30 min., surface sterilized by ethanol $(70 \%)$ for 1 sec., after that a part of every group was sterilized by $1 \% \mathrm{v} / \mathrm{v}$ commercial sodium hypochlorite $(\mathrm{NaOCl})$ for $30 \mathrm{~min}$. in case of coated seeds and 15 min. only in case of de-coated seeds, while the other part was sterilized by $30 \%$ hydrogen peroxide $\left(\mathrm{H}_{2} \mathrm{O}_{2}\right)$ for $30 \mathrm{~min}$. in case of coated seeds and 15 min. only for de-coated seeds and all seeds were washed 3 times with distilled sterilized water for $5 \mathrm{~min}$. to remove residuals of sterilization solution.

\subsection{Seed germination}

Sterilized seeds were cultured on hormones free MS media ( Murashige and Skoog,1962) supplemented with (Mccown woody plant vitamin mixture), which contains glycine $(2.00 \mathrm{mg} / \mathrm{L})$, myo-insitole $(100.00 \mathrm{mg} / \mathrm{L})$, nicotinic acid $(0.50$ $\mathrm{mg} / \mathrm{L})$, pyridoxine-HCL $(0.50 \mathrm{mg} / \mathrm{L})$ and thiamine-HCL $(1.00 \mathrm{mg} / \mathrm{L})$ with addition of 30 $\mathrm{gm} / \mathrm{L}$ sucrose and $2.5 \mathrm{gm} / \mathrm{L}$ gelrite, $\mathrm{pH}$ was adjusted at $5.8 \pm 0.1$ prior to autoclaving at $1.5 \mathrm{~kg}$ $\mathrm{cm}^{-2}$ for $20 \mathrm{~min}$. at $121 \mathrm{C}^{\mathrm{o}}$.

Each treatment was divided into two groups one was incubated in the dark and the other was incubated in the light with 16 the $\mathrm{h}$ photoperiod (cool white fluorescent light, $40 \mu \mathrm{mol} \mathrm{m} \mathrm{s}^{-1}$ ) and all groups were incubated at room temperature $\left(25 \pm 2{ }^{\circ} \mathrm{C}\right)$ for germination.

Data of germination were collected weekly through seven weeks from culture date; also the percentage of seed germination was calculated using the following equation:

Percentage of germination $=$ Germinated seeds $\times 100$

\section{4. ormone treatments (callus initiation media)}

Sterilized seedlings $(5 \mathrm{~cm}$ long) were obtained from sterilized seeds germinated in vitro. All parts of seedlings were used in culture (leaves, stems and roots) as explants to determine which part is the best. Segments $(10 \times 5 \mathrm{~mm})$ were cultured on MS full strength media supplemented with Thidizuron (TDZ) at concentrations $(0,0.1,0.5,1$, 2, 3, 4 and $5 \mathrm{mg} /$ liter). Explants (3 explants / jar) were cultured in small jars containing media (40 $\mathrm{ml} / \mathrm{each}$ ) and every treatment had 3 replicates.

All treatments were incubated at $25{ }^{\circ} \mathrm{C} \pm 2$ in light, callus weight was recorded after 45 day of culture.

\subsection{Multiplication stage}

The initiated callus resulting from each of TDZ treatments was subcultured on two kinds of MS media, one had the same concentration of hormones and the other was free of hormones to investigate the effect of hormones on growth and development, The number of shoots per treatment was recorded.

\subsection{Rooting stage}

The shoots which appeared after 45 days from subculturing callus were separated and transplanted on rooting media (MS medium free of hormone).

\subsection{Experiment layout}

The layout of the experiments was statistically analyzed using a randomized complete block design according to Gomez and Gomez (1984) by M-stat program.

\section{RESULTS AND DISCUSSION 3.1. Seed germination}

The data in Table 1 and Fig. 1 reveal that the highest germination percentage of seeds (38.89\%) was obtained from the coated seeds sterilized with $\mathrm{H}_{2} \mathrm{O}_{2}$ and incubated under light condition for 6 or 7 weeks. Coated seeds sterilized with $\mathrm{NaOCl}$ and incubated in the light gave $(27.78 \%)$ only for the last four weeks which was equal to the germination percentage of coated seeds incubated in the dark and sterilized by $\mathrm{H}_{2} \mathrm{O}_{2}$ or $\mathrm{NaOCl}$.

De-coated seeds incubated in the light and sterilized with $\mathrm{H}_{2} \mathrm{O}_{2}$ gave $16.67 \%$ germination percentage compared with only $11.11 \%$ for those incubated in the dark, or de-coated seeds sterilized with $\mathrm{NaOCl}$ and incubated in the light or the dark. It may be concluded that seed coat and light increased seeds germination, especially in the case of using $\mathrm{H}_{2} \mathrm{O}_{2}$ more than using $\mathrm{NaOCl}$, and this may be attributed to the ability of $\mathrm{H}_{2} \mathrm{O}_{2}$ to encourage seed germination beside its sterilization 
properties without harmful residual or side effect on seeds and medium. This result was confirmed by (Curvetto et al., 2006) who reported that $\mathrm{H}_{2} \mathrm{O}_{2}$ used as an earlier method in sterilization when used in a medium culture for Orchid seeds without the need of autoclaving.

Light had a role in increasing seed germination presence increase and encouraged seed germination, which was observed in all treatments. In contrast, Harbage, (2001) reported that seed germination of Echinacea increased from $50 \%$ to $97 \%$ when removing 0 to 2 layers of seed coat.

Table (1): Percentage of seed germination after seven weeks from culture.

\begin{tabular}{|c|c|c|c|c|c|c|c|c|}
\hline \multirow{3}{*}{ Weeks } & \multicolumn{6}{|c|}{ Seed germination \% } \\
\cline { 2 - 9 } & \multicolumn{3}{|c|}{ Seeds without coat } & \multicolumn{4}{c|}{ Seeds with coat } \\
\cline { 2 - 9 } & \multicolumn{2}{|c|}{$\mathbf{H}_{2} \mathbf{O}_{2}$} & \multicolumn{2}{|c|}{ NaOCl } & \multicolumn{2}{|c|}{$\mathbf{H}_{2} \mathbf{O}_{2}$} & \multicolumn{2}{c|}{ NaOCI } \\
\cline { 2 - 9 } & Light & Dark & Light & Dark & Light & Dark & Light & Dark \\
\hline $1^{\text {st }}$ & $0 \%$ & $0 \%$ & $0 \%$ & $0 \%$ & $0 \%$ & $0 \%$ & $0 \%$ & $0 \%$ \\
\hline $2^{\text {nd }}$ & $11.11 \%$ & $5.5 \%$ & $11.11 \%$ & $0 \%$ & $11.11 \%$ & $11.11 \%$ & $5.5 \%$ & $0 \%$ \\
\hline $3^{\text {rd }}$ & $11.11 \%$ & $11.11 \%$ & $11.11 \%$ & $11.11 \%$ & $27.78 \%$ & $22.22 \%$ & $22.22 \%$ & $22.22 \%$ \\
\hline $4^{\text {th }}$ & $16.67 \%$ & $11.11 \%$ & $11.11 \%$ & $11.11 \%$ & $33.33 \%$ & $22.22 \%$ & $27.78 \%$ & $27.78 \%$ \\
\hline $5^{\text {th }}$ & $16.67 \%$ & $11.11 \%$ & $11.11 \%$ & $11.11 \%$ & $33.33 \%$ & $27.78 \%$ & $27.78 \%$ & $27.78 \%$ \\
\hline $6^{\text {th }}$ & $16.67 \%$ & $11.11 \%$ & $11.11 \%$ & $11.11 \%$ & $38.89 \%$ & $27.78 \%$ & $27.78 \%$ & $27.78 \%$ \\
\hline $7^{\text {th }}$ & $16.67 \%$ & $11.11 \%$ & $11.11 \%$ & $11.11 \%$ & $38.89 \%$ & $27.78 \%$ & $27.78 \%$ & $27.78 \%$ \\
\hline
\end{tabular}

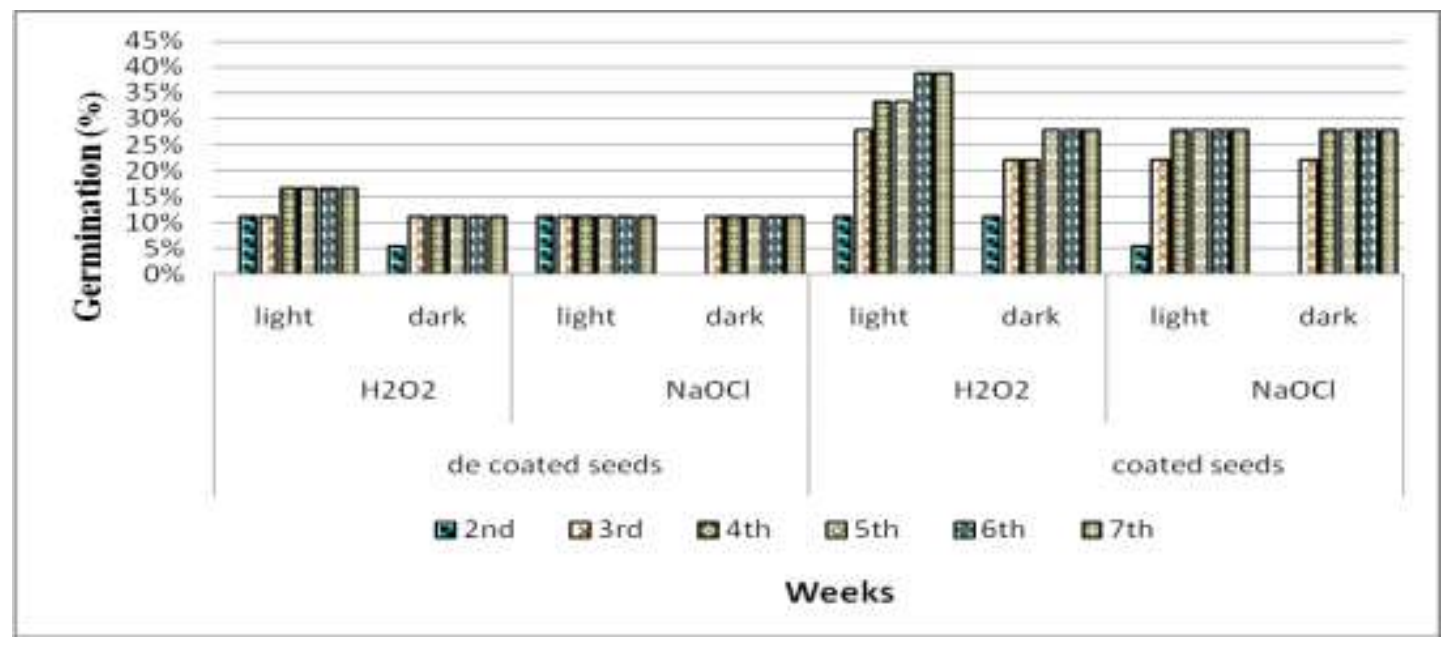

Fig.(1): Percentage of seeds germinated in vitro using two kinds of sterilization solutions under light and dark conditions for both coated and decoated seeds of Echinacea purpurea.

percentage However, this disagrees with Romero et al. (2005) who found that the germination of $E$. purpurea was $7 \%$ greater under dark. The difference may have resulted from the interference between $\mathrm{H}_{2} \mathrm{O}_{2}$ and light.

It is clear that the outer coat of the seeds was important for embryo protection from the side effect of the sterilization substances, and its

\subsection{Callus induction}

The data illustrated in Table 2 and Fig 2 show that TDZ hormone application positively affected callus production as the concentration was raised to reach the maximum weight $(12.37 \mathrm{gm})$ for leaf explants at $2 \mathrm{mg} / \mathrm{L}$, while for the stem explants it was (11.94 gm) at $1 \mathrm{mg} / \mathrm{L} \mathrm{TDZ}$. 
All values decreased sharply to the minimum at the highest concentration of TDZ. In the case of root explants, it was found that the highest value $(7.3 \mathrm{gm})$ was obtained at the level of 0.5 $\mathrm{mg} / \mathrm{L} \mathrm{TDZ}$, then decreased as the concentration was raised to give the lowest weight $(0.20 \mathrm{mg})$ $5 \mathrm{mg} / \mathrm{L}$ TDZ .
Although the weight of stem callus at $1 \mathrm{mg}$ TDZ/L was relatively similar to that of leaf callus at $2 \mathrm{mg} / \mathrm{L}$, but there were no shoots formed on stem explants callus as compared with leaf explants.

In the case of leaf callus, the highest number of shoots (3 shoots/replicate) was obtained at $1 \mathrm{mg} / \mathrm{L}$

Table (2):Fresh callus weight (gm) at different concentrations of TDZ hormone.

\begin{tabular}{|c|c|c|c|c|}
\hline TDZ mg\L & Leaf & Stem & Root & Mean \\
\hline 0 & 0.58 & 0.2 & 0.1 & 0.29 \\
\hline 0.1 & 5.42 & 5.08 & 2.06 & 4.19 \\
\hline 0.5 & 9.49 & 11.02 & 7.30 & 9.27 \\
\hline 1 & 10.89 & 11.94 & 1.24 & 8.02 \\
\hline 2 & 12.37 & 1.42 & 0.47 & 4.75 \\
\hline 3 & 6.88 & 0.71 & 0.27 & 2.62 \\
\hline 4 & 5.03 & 1.39 & 0.43 & 2.28 \\
\hline 5 & 3.71 & 0.7 & 0.20 & 1.5 \\
\hline Mean & 6.79 & 4.05 & 1.51 & \\
\hline
\end{tabular}

LSD value $=1.47$ at alpha 0.05

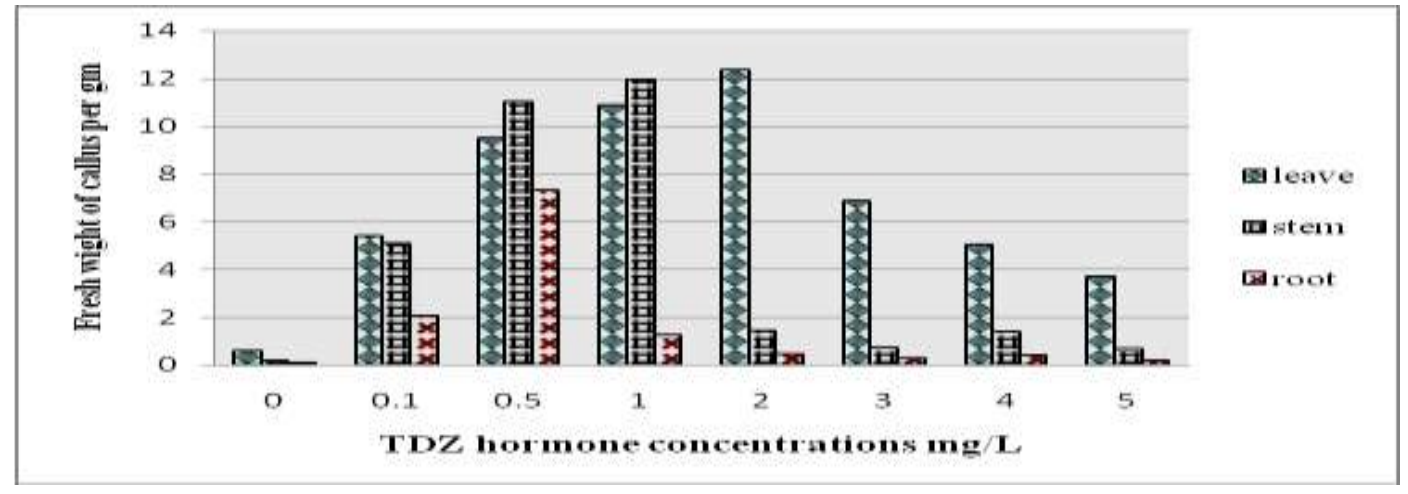

Fig. (2): Effect of different concentrations of TDZ hormone on callus initiation for different explants of Echinacea purpurea.

\subsection{Shoot multiplication}

The number of shoots formed from the callus of leaf explants was significantly higher than that formed on the callus of stem and root explants regardless whether the explants were grown on hormone free media or on the same hormone concentrations as those used during callus induction (Tables 3 and 4). followed by $2.00,1.33$ and 0.66 shoots/replicate which were obtained at 2.0,0.5 and $3.0 \mathrm{mg} / \mathrm{LTDZ}$ respectively. The other concentrations did not show any shoot development.

All leaf callus which was obtained from media supplemented with different concentrations of TDZ and subcultured on hormone free media developed shoots. The highest number of shoots

Table (3): Number of shoots formed from callus on MS media containing the initial TDZ conc.

\begin{tabular}{|c|c|c|c|c|}
\hline TDZ ( mglL) & Leaf & Stem & Root & Mean \\
\hline $\mathbf{0}$ & $\mathbf{0}$ & $\mathbf{0}$ & $\mathbf{0}$ & $\mathbf{0}$ \\
\hline $\mathbf{0 . 1}$ & $\mathbf{0}$ & $\mathbf{0}$ & $\mathbf{0}$ & $\mathbf{0}$ \\
\hline $\mathbf{1}$ & $\mathbf{1 . 3 3}$ & $\mathbf{0}$ & $\mathbf{0 . 3 3}$ & $\mathbf{0 . 5 5}$ \\
\hline $\mathbf{2}$ & $\mathbf{3 . 0 0}$ & $\mathbf{0}$ & $\mathbf{0}$ & $\mathbf{1 . 0 0}$ \\
\hline $\mathbf{3}$ & $\mathbf{2 . 0 0}$ & $\mathbf{0}$ & $\mathbf{0}$ & $\mathbf{0 . 6 6}$ \\
\hline 4 & $\mathbf{0 . 6 6}$ & $\mathbf{0}$ & $\mathbf{0}$ & $\mathbf{0 . 2 2}$ \\
\hline $\mathbf{5}$ & $\mathbf{0}$ & $\mathbf{0}$ & $\mathbf{0}$ & $\mathbf{0}$ \\
\hline Mean & $\mathbf{0}$ & $\mathbf{0}$ & $\mathbf{0}$ & $\mathbf{0}$ \\
\hline
\end{tabular}

LSD value $=0.55$ at alpha $=0.050$ 


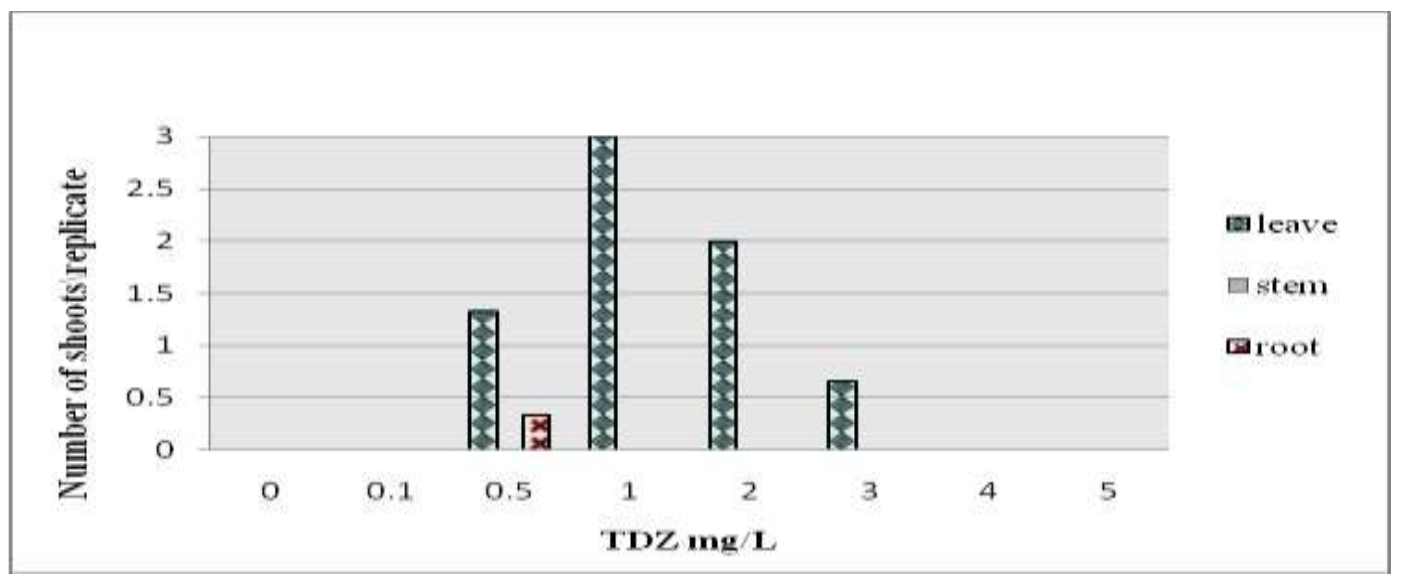

Fig.(3): Number of shoots as affected by different TDZ concentrations after subculturing on media have the same previous concentrations.

Table (4): Number of shoots formed from callus sub cultured on free MS media.

\begin{tabular}{|c|c|c|c|c|}
\hline TDZ $(\mathbf{m g} \backslash \mathbf{L})$ & Leaf & Stem & Root & Mean \\
\hline $\mathbf{0}$ & $\mathbf{0}$ & $\mathbf{0}$ & $\mathbf{0}$ & $\mathbf{0}$ \\
\hline $\mathbf{0 . 1}$ & $\mathbf{2 . 6 6}$ & $\mathbf{0 . 3 3}$ & $\mathbf{0}$ & $\mathbf{1}$ \\
\hline $\mathbf{0 . 5}$ & $\mathbf{0 . 6 6}$ & $\mathbf{0}$ & $\mathbf{0}$ & $\mathbf{0 . 2 2}$ \\
\hline $\mathbf{1}$ & $\mathbf{2 . 3 3}$ & $\mathbf{0}$ & $\mathbf{0}$ & $\mathbf{0 . 7 7}$ \\
\hline $\mathbf{2}$ & $\mathbf{2 . 3 3}$ & $\mathbf{0}$ & $\mathbf{0}$ & $\mathbf{0 . 7 7}$ \\
\hline $\mathbf{3}$ & $\mathbf{2}$ & $\mathbf{0}$ & $\mathbf{0}$ & $\mathbf{0 . 6 6}$ \\
\hline $\mathbf{4}$ & $\mathbf{2 . 3 3}$ & $\mathbf{0}$ & $\mathbf{0}$ & $\mathbf{0 . 7 7}$ \\
\hline $\mathbf{5}$ & $\mathbf{0 . 6 6}$ & $\mathbf{0}$ & $\mathbf{0}$ & $\mathbf{0 . 2 2}$ \\
\hline Mean & $\mathbf{1 . 6 2}$ & $\mathbf{0 . 0 4}$ & $\mathbf{0}$ & \\
\hline
\end{tabular}

LSD value $=0.8805$ at alpha $=0.050$

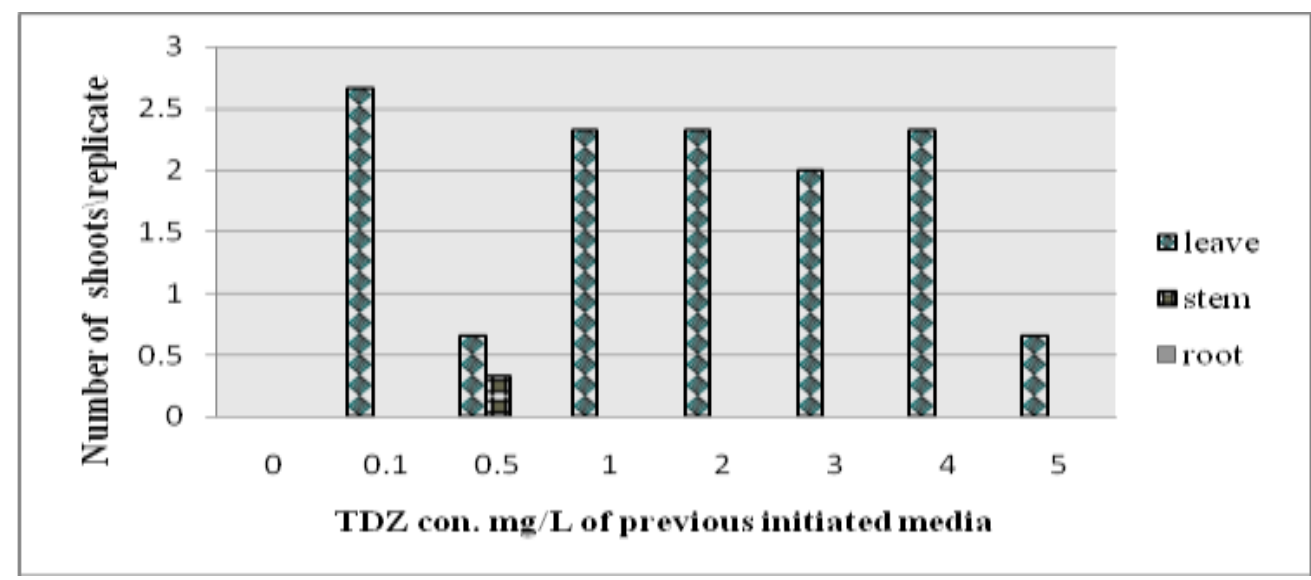

Fig.(4): Number of shoots obtained from callus subcultured on free hormone media.

(2.66 shoots/replicate) obtained from leaf callus formed on media contained $0.1 \mathrm{mg} / \mathrm{L} \mathrm{TDZ}$, while leaf callus formed with treatments 1.0, 2.0 and 4.0 $\mathrm{mg} / \mathrm{L}$ TDZ gave similar number of shoots $(2.33$ shoots/replicate) followed by 2.0 shoots/replicate at $3.0 \mathrm{mg} / \mathrm{L} \mathrm{TDZ}$, and 0.66 shoots/replicate at 0.5 or $5 \mathrm{mg} / \mathrm{LTDZ}$. This may be explained by assuming that the presence of TDZ in the subcultured media inhibited shoot differentiations from callus, while using hormone free media 
promoted shoot development.

Most of the shoots formed roots before separating them and subculturing on rooting media. Also derooted shoots which were separated and subcultured on rooting media easily formed roots after 3 weeks from subculturing date. This result agrees with Koroch et al. (2002), who found that high rooting and survival of plantlets was achieved using MS media without plant growth regulators, Also Lakshmanan et al. (2002) mentioned that rooting of in vitro developed shoots was achieved relatively easily with Murashage and Skoog basal medium rather than with auxin enriched media.

\section{REFERENCES}

Barrett B. (2003). Medicinal properties of Echinacea: A critical Review. Phytomedicine, 10: 66-86.

Bone K. (1997). Echinacea:What makes it work? Alternative Medicine Review, 2 (2).

Coker P. S. and Camper N.D. (2000). In vitro Culture of Echinacea purpurea L. Journal of herbs, Spices \& Medicinal plants, 7(4).

Curvetto N., Marinangeli P. and Mockel G. (2006). Hydrogen peroxide in micropropagation of Lilium. A comparison with a traditional methodology .Biocell, 30(3):497-500.

Gomez K.H. and Gomez A.A. (1984). Statistical Procedures for Agriculture Research. John Wiley and Sons, Inc. New York.

Harbage J.F. (2001). Micropropagation of Echinacea angustifolia, E. pallida and E. purpurea from stem and seed explants. HortScience 36(2):360-364.

Huetteman C.A. and Preece J.E. (1993). Thidiazuron: a potent cytokinin for woody plant tissue culture. Plant Cell Tiss.Org. Cult. 33: 105-119.

Koroch A., Juliani H.R., Kapteyn J. and Simon J.E. (2002). In vitro regeneration of Echinacea purpurea from leaf explants. Plant Cell, Tissue and Organ Culture, 69:79-83.

Lakshmanan P., Danesh M. and Taji A. (2002). Production of four commercially cultivated Echinacea species by different methods of in vitro regeneration.Journal of Horticulture Science \&Biotechnology 77(2)158-163.

Letchamo W., Livesey J., Arnason T.J., Bergeron C., and Krutilina V.S. (1999). Chichoric acid and isobutylamide content in Echinacea purpurea as influenced by flower development stages. Perspectives On New Crops And New Uses J.Janick (ed.) ASHS Press, Alexandria, VA., USA.

Liu C.Z., Murch S.J., Demerdash E.L. and Saxena P.K. ( 2003). Regeneration of the Egyptian medicinal plant Artemisia judaica L. Plant Cell Rep. 21: 525-530.

Murashige T. and Skoog F. (1962). A revised medium for rapid growth and bioassays with tobacco tissue cultures. Physiol. Plant.15:473-497.

Romero F.R., Delate K. and Hannapel D.J. (2005). The effect of seed source, light during germination, and coldmoist stratification on seed germination in three species of Echinacea for organic production. HortScience. 40(6): 17511754.

\footnotetext{
إكثار نبات الإخناسيا Echinacea purpurea (L.) Moench لبٕستخام تقنية زراعة الانسجة$$
\text { سلوى صقر - أمل عبدو - شاديه قطب* - نيفين عيد* }
$$$$
\text { قسم بساتين الزينة ـ كلية الزراعة - جامعة القاهرة- الجيزة -مصر. }
$$$$
\text { * قسم النباتات الطبية و العطرية ـ معهد بحوث البساتين ـ مركز البحوث الزية الزر اعيةـ الجيزة ـمصر. }
$$$$
\text { تم إجر اء هذا البحث بمعمل زر اعة الأنسجه بمعهد بحوث البساتين بهدف تقييم أفضل تركيز من هرمون الثيديازورون }
$$

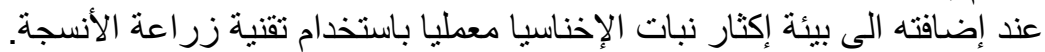

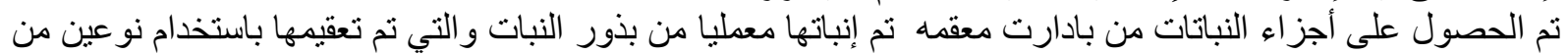

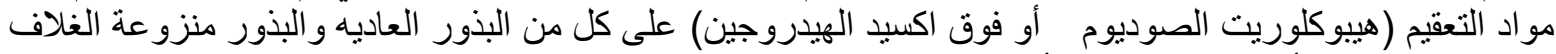$$
\text { الخارجي مع تقييم تأثثير الضوء على الضى الأنبات . }
$$ 
تم إستخدام أجزاء مختلفه من النبات (الأوراق_ السيقان_ الجذور ). و زر زاعتها على بيئة (مور اثيج وسكوج) محتويه على تركيزات مختلفه من هرمون الثيديازورون (صفر -01 جزء نباتي مستخدم من النبات نم نقل الكالس المتكون من الأجز اء النباتيه المزروعة على النى التركيزات السابقه على نوعين من بيئة (مور اثنيج وسكوج)

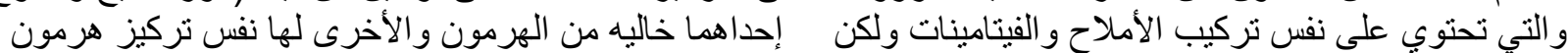

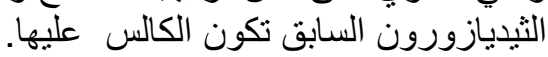

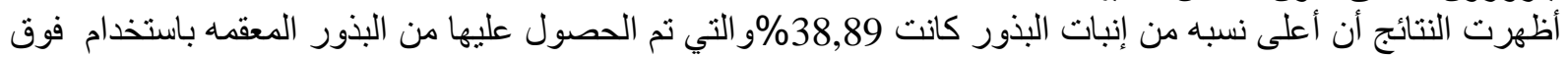

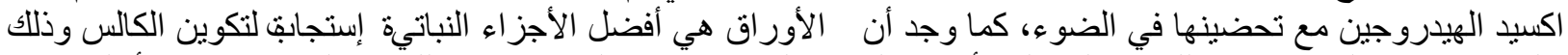

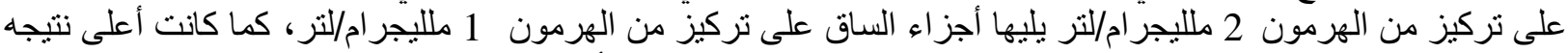

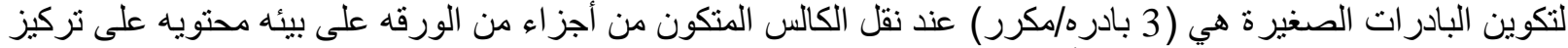
من الهرمون 1 ملليجر ام/لتر على بيئه أخرى لهاديا نفس نركيز الهرمون.

المجلة العلمية لكلية الزراعة ـ جامعة القاهرة ـ المجلا (61) العدد الهثى (ابريل 2010):228-222. 